\title{
Variance Decomposition of Emissions, FDI, Growth and Imports in GCC countries: A Macroeconomic Analysis
}

\author{
Ahmed Saddam \\ Faculty of Administration and Economics, University of Basrah, Iraq \\ Email: ahmed_saddam@live.com
}

\begin{abstract}
This paper provides an empirical evidence of the variance decomposition of carbon dioxide emissions, FDI inflows, GDP per capita and imports in GCC countries; UAE, Bahrain, Saudi Arabia, Oman, Qatar and Kuwait. The method adopted is based on the Vector Error Correction Model (VECM). It examined a 256 observation for the duration 2000 - 2010. We found that FDI inflows have a significant variance to GDP. And the increase of level of carbon dioxide emissions is highly related to FDI and commodity imports in which GCC economies have not taken into account in their environmental consideration. The study is valuable for organizations and government policymakers given that the importance of industry engagement for organizational outcomes has been confirmed. Correspondingly, significant implications for organizations exist, as they are aware of which parts of their operations and conditions will drive relevant talent to engage in the organizations' work. This paper provides an empirical evidence of the variance decomposition of carbon dioxide emissions, FDI inflows, GDP per capita and imports in GCC countries; UAE, Bahrain, Saudi Arabia, Oman, Qatar and Kuwait. The method adopted is based on the Vector Error Correction Model (VECM). It examined a 256 observation for the duration $2000-2010$. We found that FDI inflows have a significant variance to GDP. And the increase of level of carbon dioxide emissions is highly related to FDI and commodity imports in which GCC economies have not taken into account in their environmental consideration. This paper provides an empirical evidence of the variance decomposition of carbon dioxide emissions, FDI inflows, GDP per capita and imports in GCC countries; UAE, Bahrain, Saudi Arabia, Oman, Qatar and Kuwait. The method adopted is based on the Vector Error Correction Model (VECM). It examined a 256 observation for the duration $2000-2010$. We found that FDI inflows have a significant variance to GDP. And the increase of level of carbon dioxide emissions is highly related to FDI and commodity imports in which GCC economies have not taken into account in their environmental consideration.
\end{abstract}

Keywords: Emissions, FDI, import, GCC, VECM, variance decomposition

\section{Introduction}

Two conflicting hypotheses have emerged from the debate about the environment. The first one, the pollution haven hypothesis $(\mathrm{PHH})$ suggests that developed countries impose strict environmental policies and distort the existing pattern of comparative advantage when the polluting industries shift their operations from the developed to the developing countries to become "Pollution Haven". The second is the factor endowment hypothesis (FEH) which assumes that trade liberalization will lead to consistency of trade pattern. This notion is based on the Heckscher-OhlinVanek (HOV) theory of comparative advantage and consists of factor endowment differentials (Saddam 2014). Moreover, the developed countries are well endowed with capital since capital-intensive goods are often also pollutionintensive (Fatimah Kari 2013). Factor endowment theories of international trade predict that developed countries specialize in polluting goods. This means that $\mathrm{PHH}$ is in direct conflict with the FEH. Accordingly, developing 
countries have become a good laboratory for testing PHH and FEH. However, many studies paid attention for both theories and showed interest in knowing how countries can be affected externally or internally. For instance, Thai economy is subjected to pollution haven matters, and no factor endowment where the result of study confirms that this country is a pollution haven and the effect of FDI on environment has not been environmentally friendly (Mukhopadhyay, 2008). Hence, it is apparent that sound policies were not involved for sustaining environment quality in order to keep trade development in the future since the country's economy depends on export. There is a need for providing financial incentives to establish green industries and encourage using imported technology for the production of green products. Furthermore, there is an inverse relationship between environmental degradation and per capita national income where economic growth reduces the environmental impact resulting from various economic activities. Also, the trade has a neutral impact on environmental degradation (Stern 1996).

On the contrary, a significant relationship between GDP and carbon dioxide emissions (CO2) exist in developed countries (Thomas 2009). The rapid movement of capital and expansion in industrial base has increased level of carbon dioxide emissions. Therefore, we can say that protecting the natural environment could be via improving energy efficiency use and reducing level of emissions to achieve high economic growth at less environmental cost and with a more positive impact on quality of life. However, the level of per capita could affect negatively or positively on the environment. In this context, in Canada for example, there is a positive relationship between per capita GDP and carbon dioxide emissions. This fact, however, interpreted by the valuable role of income, where Canada does not have a high level of per capita GDP to prevent the effect of other environmental problems associated with economic growth (Quentin 2002). Meaning that the level of environmental degradation, declining with increasing per capita incomes, where the positive relationship between per capita income and some indicators of a declining measures of environmental degradation. Moreover, the high level of per capita income will improve the level of eco-efficiency in the long term. Accordingly, the economic policy should follow comprehensive steps to reduce level of pollution via shifting from the production that have high pollution rate in order to mitigate the environmental degradation which associate with the total consumption and economic activities. The major purpose of this paper is to extrapolate whether GCC countries are subjected to "PHH" or "FEH". This investigation will be based on analysing results of variance decomposition methods. Hence, it will specify how much external factors like FDI and imports affect the level of carbon dioxide emissions in GCC countries.

\section{Review of Literature}

The linkage between economic growth, foreign trade and environmental degradation usually indicates that the trade may influence the EKC relationship both positively and negatively. It also reveals that GDP has a high positive significant impact on environment, while the trade doesn't (Abdulai, 2009; Fatimah Kari, 2012). Moreover, the income variable indicates that there is an EKC implication. In this respect, Bruyn (1998), Nickerson (2004) stated that the environmental pollution is linked directly to economic growth. This study indicated that the best way to reduce the effect of environmental pollution is to increase the level of investment in high technology to achieve rapid economic growth and increase the level of value added. It leads to the fast economic growth and reduce the effect of environmental pollution resulting from the increased production. The study showed that the economic growth has a direct positive impact on the levels of pollution in spite the increase of level of pollution resulting from economic growth. This pollution could be declined over the time via economic progresses that occur in the level of advanced technology. In other words, at the long-term, the continued economic growth will lead to accumulate advanced technologies, which will be placed instead of the old technologies, and this progress could be induced reducing level of pollution. As it was reported when a country doesn't have institutional capacities to set up proper environmental policies and protecting some sectors, the environmental problem will affect the country even though there is a rise in the level of income. Moreover, solving environmental issue needs international cooperative actions to unify policies for achieving suitable economic growth with less level of pollution. Besides, $\mathrm{CO} 2, \mathrm{NO} 2$, and $\mathrm{CH} 4$ are the three most widespread greenhouse gases (GHGs), where the electricity consumption and the related $\mathrm{CO} 2$ burns from oil and gas combustion in GCC countries are affecting substantial increase in the level of air pollution. These countries contribute significantly to the global $\mathrm{CO} 2$ emissions and that the majority of their emissions are concentrated in the energy extraction and manufacturing sectors (Qader 2009). Moreover, it refers that the current rates of electricity consumptions and related $\mathrm{CO} 2$ emissions in GCC countries are higher than that of other developed countries of similar population. The study recommended using renewable and cleaner sources of power generation. Ekins (1999) found that the relationship between economic growth and the environment could be positive. He reports that the government pay 


\section{Ahmed Saddam \\ Variance Decomposition of Emissions, FDI, Growth and Imports in GCC countries: A Macroeconomic Analysis}

more concern towards the environment parallel to its economic growth. Moreover, Ekins sees that the population growth combined with increased level of economic activities which induce damage to the environment as a result of higher level of production and consumption represents a big challenge. He reports that the human welfare is also associated positively in the relation between economic growth and environmental degradation. (Kheder 2010). Furthermore, an empirical analysis has estimated three simultaneous equations to model the determination of FDI. It confirms a negative impact of environmental regulation on FDI; French manufacturing FDI have led to increase in the level of emissions and pollution in host countries (Kheder 2010). However, the relationship between GDP and the emissions could vary based on the types of pollutants and regions. For example, the relationship between economic growth and environment in China is complicated. The study recommended using stricter environmental regulations. Furthermore, FDI may increase the level of emissions and provides convincing supportive evidence for pollution haven hypothesis

From the above, it is obvious that FDI and foreign trade have an effect on environmental quality, where each contribution does not necessarily support PHH, EFH and EKC, where trade assists promotion in economic growth, which in turn is an indirect channel of effect on environment. In addition, the environmental policies are a major factors to control pollution, in this context, income can affect positively on the criteria of environmental efficiency (Lee 2005). Therefore, in this paper, we will try to figure up how much FDI, growth represented by GDP and import contribute in the level of carbon dioxide emissions in GCC countries.

\section{Methodology}

The model specification in this research is estimated based on annual time series data over the period $2000-2010$. The data for all variables of GCC countries are collected from IMF and SESRIC, WB, and AMF database. The functional relation initially is represented as follows:

$C o_{2}=f(M, G D P, F D I)$

Where, Co2 $\neg \neg \neg$ represents a carbon dioxide emission per capita measured by metric ton, $\mathrm{M}$ - commodity imports, GDP - Gross Domestic Product per capita, and FDI - foreign direct investment inflows measured. However, the data used in logarithmic and the econometric model is written in the following model.

$$
\log \left(C_{2}\right)=B_{0}+B_{1} \log (M)+B_{2} \log (G D P)+B_{3} \log (F D I)+u_{i}
$$

Where B0 is the intercept, and ui represents error term. However, we commence the analysis by testing the time series data, and in order to avoid spurious regression, a group unit root test will be conducted. However, for using VECM model, we have to ensure possibility of the long-run equilibrium among the variables examined. Therefore, the trace test will be engaged in this study.

\section{Results}

A group unit root test is used for the data adopted in this study. Table 1 depicts that the test result for stationary of a 257 observation. The null hypothesis postulated that there is a unit root process for the data of the study. However, throughout the result, we see that the probability value of Pearson and Shin, ADF - Fisher Chi-Square and PP - Fisher Chi-Square are statistically significant at the 1 percent level. Accordingly, the null hypothesis will be rejected and the alternative one will be accepted as it is shown in the following table: 
Table 4-1 A group unit root test for the data of the study

Group unit root test: Summary

Series: FDIN, GDP, $\mathrm{LOGCo}_{2}, \mathrm{M}$

Sample: 166

Exogenous variables: Individual effects

Automatic selection of maximum lags

Automatic lag length selection based on SIC: 0 to 3

Newey-West automatic bandwidth selection and Bartlett kernel

\begin{tabular}{|c|c|c|c|c|}
\hline Method & Statistic & Prob.** & $\begin{array}{l}\text { Cross- } \\
\text { sections }\end{array}$ & Obs \\
\hline \multicolumn{5}{|c|}{ Null: Unit root (assumes common unit root process) } \\
\hline Levin, Lin \& Chu t* & -3.18611 & 0.0007 & 4 & 257 \\
\hline
\end{tabular}

Null: Unit root (assumes individual unit root process)

\begin{tabular}{lllll}
\hline Im, Pesaran and Shin W-stat & -5.76990 & 0.0000 & 4 & 257 \\
ADF - Fisher Chi-square & 57.7292 & 0.0000 & 4 & 257 \\
PP - Fisher Chi-square & 95.5038 & 0.0000 & 4 & 260
\end{tabular}

\section{Table 4-2 Lag order selection criteria}

VAR Lag Order Selection Criteria

Endogenous variables: FDIN GDP $\mathrm{LOGCo}_{2} \mathrm{M}$

Exogenous variables: $\mathrm{C}$

Date: 02/04/13 Time: $15: 30$

Sample: 166

Included observations: 60

\begin{tabular}{ccccccc}
\hline Lag & LogL & LR & FPE & AIC & SC & HQ \\
\hline 0 & -798.2723 & NA & 4832692. & 26.74241 & 26.88203 & 26.79702 \\
1 & -698.3245 & $183.2377^{*}$ & $294840.8^{*}$ & $23.94415^{*}$ & $24.64226^{*}$ & $24.21722^{*}$ \\
2 & -688.4770 & 16.74080 & 364706.0 & 24.14923 & 25.40584 & 24.64076 \\
3 & -679.4186 & 14.19137 & 468376.0 & 24.38062 & 26.19572 & 25.09061 \\
4 & -665.8614 & 19.43202 & 526651.0 & 24.46205 & 26.83564 & 25.39049 \\
5 & -655.1721 & 13.89611 & 667377.8 & 24.63907 & 27.57115 & 25.78597 \\
6 & -648.0421 & 8.318278 & 983732.5 & 24.93474 & 28.42531 & 26.30009 \\
\hline
\end{tabular}

LR: sequential modified LR test statistic (each test at $5 \%$ level)

FPE: Final prediction error

AIC: Akaike information criterion

SC: Schwarz information criterion

HQ: Hannan-Quinn information criterion 
A group unit root test is used for the data adopted in this study. Table 4-1 depicts that the test result for stationary of a 257 observation. The null hypothesis postulated that there is a unit root process for the data of the study. However, throughout the result, we see that the probability value of Pearson and Shin, ADF - Fisher Chi-Square and PP - Fisher Chi-Square are statistically significant at the 1 percent level. Accordingly, the null hypothesis will be rejected and the alternative one will be accepted as it is shown in the table above. Table 4-1 indicates the absence of unit root and the data used is stationary. So it is statistically valid for regressing the model adopted, and the economic analysis is reliable for this study. In addition, a VAR lag order selection criteria exhibit that one lag is an ideal lag for the model studied as shown in table 4-2 above. However, we see obviously that five criteria indicated the one lag. We, therefore, run the VECM model with one lag. Furthermore, the trace test for co-interaction is regressed to diagnose the presence of a long run association among the variables of this study. However, the outcome shows that both tests values - trace statistic and Max-Egin - are statistically significant at the 1 percent level. Tables 4-3 and 4-4 represent this fact:

Table 4-3 Trace Statistic Test for Co-integration

Sample (adjusted): 466

Included observations: 63 after adjustments

Trend assumption: Linear deterministic trend

Series: FDIN GDP LOGCO2 M

Lags interval (in first differences): 1 to 2

Unrestricted Co-integration Rank Test (Trace)

\begin{tabular}{ccccc}
\hline $\begin{array}{c}\text { Hypothesized } \\
\text { No. of CE(s) }\end{array}$ & Eigenvalue & $\begin{array}{c}\text { Trace } \\
\text { Statistic }\end{array}$ & $\begin{array}{c}0.05 \\
\text { Critical Value }\end{array}$ & Prob.** \\
\hline None * & 0.459090 & 76.78519 & 47.85613 & 0.0000 \\
At most 1 $*$ & 0.395892 & 38.07149 & 29.79707 & 0.0045 \\
At most 2 & 0.068384 & 6.319398 & 15.49471 & 0.6578 \\
At most 3 & 0.029043 & 1.856835 & 3.841466 & 0.1730 \\
\hline
\end{tabular}

Source: By the author based on the result of E-views software.

Trace test indicates 2 co-integrating eqn(s) at the 0.05 level

* denotes rejection of the hypothesis at the 0.05 level

**MacKinnon-Haug-Michelis (1999) p-values

Table 4-4 Max-Eigen Statistic Test for Co-integration

\begin{tabular}{ccccc}
\hline $\begin{array}{c}\text { Hypothesized } \\
\text { No. of CE(s) }\end{array}$ & Eigenvalue & $\begin{array}{c}\text { Max-Eigen } \\
\text { Statistic }\end{array}$ & $\begin{array}{c}0.05 \\
\text { Critical Value }\end{array}$ & Prob.** \\
\hline None * & 0.459090 & 38.71370 & 27.58434 & 0.0013 \\
At most $1 *$ & 0.395892 & 31.75209 & 21.13162 & 0.0011 \\
At most 2 & 0.068384 & 4.462564 & 14.26460 & 0.8076 \\
At most 3 & 0.029043 & 1.856835 & 3.841466 & 0.1730 \\
Source: By the author based on the result of E-views software. & \\
Max-eigenvalue test indicates 2 co-integrating eqn(s) at the 0.05 level \\
* denotes rejection of the hypothesis at the 0.05 level \\
**MacKinnon-Haug-Michelis (1999) p-values
\end{tabular}


Accordingly, the co-integration exists among the variables of this study. It is statistically significant meaning that there is a long -run association among carbon dioxide emissions $\left(\mathrm{Co}_{2}\right)$, FDI, GDP and Imports $(\mathrm{M})$. In other words, the variables adopted for this model could drift together at the same trend (Greene, 2003). Therefore, the Variance Decomposition method is regressed and the outputs will be discussed in tables 4-5, 4-6, 4-7 and 4-8.

\section{Discussions}

Table 5 shows shock of the forecast error variance of FDI. It charts that current variance of FDI inflows contribute between 100 to 71 percent over the forecasted period. However, these flows have a significant impact in which will remain highly related to its own shocks. While GDP per capita shock indicated that its portion in shock of FDI has gradually increased from 0.00 percent at the first year of forecasting to 20.17 percent at the end period. We, therefore, note that the influence of this variable is much higher in comparison to $\mathrm{Co} 2$ and $\mathrm{M}$ which are not effected variables over the forecasted ten years.

Table 5-1 Variance Decomposition of FDI inflows

\begin{tabular}{cccccc}
\hline Period & S.E. & FDIN & GDP & LOGCo $_{2}$ & M \\
\hline 1 & 36.91915 & 100.0000 & 0.000000 & 0.000000 & 0.000000 \\
2 & 39.51081 & 87.33900 & 6.520119 & 0.000211 & 6.140673 \\
3 & 40.64541 & 83.12710 & 8.411564 & 1.157544 & 7.303792 \\
4 & 42.05068 & 78.81287 & 13.14228 & 1.216165 & 6.828691 \\
5 & 43.83626 & 78.84515 & 13.41944 & 1.123625 & 6.611781 \\
6 & 44.73516 & 77.64584 & 14.56546 & 1.153233 & 6.635463 \\
7 & 46.11688 & 75.32167 & 16.58858 & 1.329232 & 6.760514 \\
8 & 47.27311 & 73.63330 & 18.14269 & 1.319104 & 6.904905 \\
9 & 48.24403 & 72.80011 & 19.03172 & 1.317256 & 6.850913 \\
10 & 49.35901 & 71.68017 & 20.17045 & 1.347132 & 6.802242 \\
\hline
\end{tabular}

Source: By the author based on the result of E-views software

Accordingly, the result above could be explained by the role of economy size and its per capita. This statement is consistent with other studies that represents GDP as a main factor for attracting more foreign direct investment (Saddam and Kari 2012). Hence, the presence of a sound economic policy is a crucial matter for maintaining this linkage and reinforcement level of economic openness via attracting foreign direct investment to sectors that could accelerate growth.

Table 5-3 represents that a shock of GDP is mainly dates back to its own shock, where the percentage of this variance ranged from 85.8 to 66.9 at the first and end period respectively. While the portion of FDI in the variance of GDP is slightly higher than that of its portion in the variance of FDI as already was noted in table 5-2.

However, its contribution amounted from 14.1 percent at the first year forecasted to 24.9 percent at the tenth year as shown in the following table: 
Ahmed Saddam

Variance Decomposition of Emissions, FDI, Growth and Imports in GCC countries: A Macroeconomic Analysis

Table 5-2 Variance Decomposition of GDP per capita

\begin{tabular}{|c|c|c|c|c|c|}
\hline Period & S.E. & FDIN & GDP & $\mathrm{LOGCo}_{2}$ & M \\
\hline 1 & 8.648739 & 14.18934 & 85.81066 & 0.000000 & 0.000000 \\
\hline 2 & 9.662565 & 21.83387 & 70.53600 & 6.516087 & 1.114044 \\
\hline 3 & 10.09517 & 20.18121 & 67.46784 & 6.114529 & 6.236415 \\
\hline 5 & 12.31248 & 23.27496 & 66.85576 & 5.468149 & 4.401137 \\
\hline 6 & 12.69330 & 23.20504 & 66.34591 & 5.468759 & 4.980286 \\
\hline 7 & 13.49206 & 23.85135 & 66.57718 & 4.955439 & 4.616024 \\
\hline 8 & 14.08249 & 24.58231 & 66.11910 & 5.061510 & 4.237073 \\
\hline
\end{tabular}

Source: By the author based on the result of E-views software.

Thus, we can specify that the GDP and FDI flows are interrelated variables in GCC economies. In other words, FDI inflows are important agent of economic growth. Since the contribution of $\mathrm{M}$ is much less than that of $\mathrm{FDI}$ and $\mathrm{Co}_{2}$, this implies that any fluctuations occur in the level of these inflows and global economy will affect more than GCC's trade with other countries. Hence, $\mathrm{Co}_{2}$ and $\mathrm{M}$ variables are not important in enhancing level of economic growth in comparison to FDI variable.

Table 5-3 illustrates that the forecast error variance of carbon dioxide emissions $\mathrm{Co}_{2}$ in GCC countries is significantly linked to its own shock, in which its variance ranged from 96.40 percent to 88.64 percent at the first and end year respectively as follows:

Table 5-3 Variance Decomposition of $\mathrm{Co}_{2}$

\begin{tabular}{cccccc}
\hline Period & S.E. & FDIN & GDP & LOGCo $_{2}$ & M \\
\hline 1 & 0.289074 & 3.258822 & 0.339835 & 96.40134 & 0.000000 \\
2 & 0.393913 & 4.459492 & 0.703484 & 94.83638 & 0.000647 \\
3 & 0.462657 & 7.600319 & 0.588627 & 91.74399 & 0.067066 \\
4 & 0.522711 & 9.127002 & 0.894525 & 89.78353 & 0.194943 \\
5 & 0.578897 & 9.077830 & 0.973196 & 89.75097 & 0.198008 \\
6 & 0.630743 & 9.383108 & 0.882874 & 89.49692 & 0.237094 \\
7 & 0.676372 & 9.676720 & 0.911793 & 89.14138 & 0.270103 \\
8 & 0.719864 & 9.823440 & 0.962486 & 88.95163 & 0.262441 \\
9 & 0.761601 & 9.996881 & 0.942874 & 88.78933 & 0.270915 \\
10 & 0.800503 & 10.12101 & 0.943568 & 88.64524 & 0.290179 \\
\hline
\end{tabular}

Source: By the author based on the result of E-views software.

In the table above we note that variance of FDI inflows is represented a 3.25 at the first period and it witnessed a gradual increase through the second until the end period forecasted reaching to 10.12 percent. Whereas GDP and M contribution were in a modest level, it does not exceed 1.00 percent all over the predicted period. However, this indicates that the increase of carbon dioxide emissions is attributed to FDI inflows as an external factor of air pollution. Accordingly, we can say that foreign investors in GCC countries did not pursue a strict environmental policy. Furthermore, this result can explain that the major GCC's FDI inflows are concentrated in energy sectors, which have an evident impact on the environment compared to sectors that are not related to energy industry. Thus, GCC countries 
have succeeded in attracting FDI, but the considerations of the environment were not taken into account. Therefore, this statement is not consistent with the target of the GCC' joint economic policy, which assert on the importance of a strict environmental policy for achieving a sustaining economic growth. Table 5-4 below illustrates that a shock of GCC's import is significantly related to its own shock. The ratios of import variance ranges from 90.21 percent to 90.63 percent during the horizon of the ten years forecasted. FDI inflows represent a modest variance in its contribution to the shock of import. GDP and $\mathrm{Co}_{2}$ didn't reflect a real impact in this context. This result, however, could be attributed to the role of FDI inflows in producing various kinds of manufacturing goods in GCC economies, where level of import could be reduced consequently. In other words, FDI inflows to GCC countries have affected level of imports more than GDP. This state also can indicate that the local producing sectors have not met the GCC' economies needs as much as FDI inflows

Table 5-4 Variance Decomposition of $M$

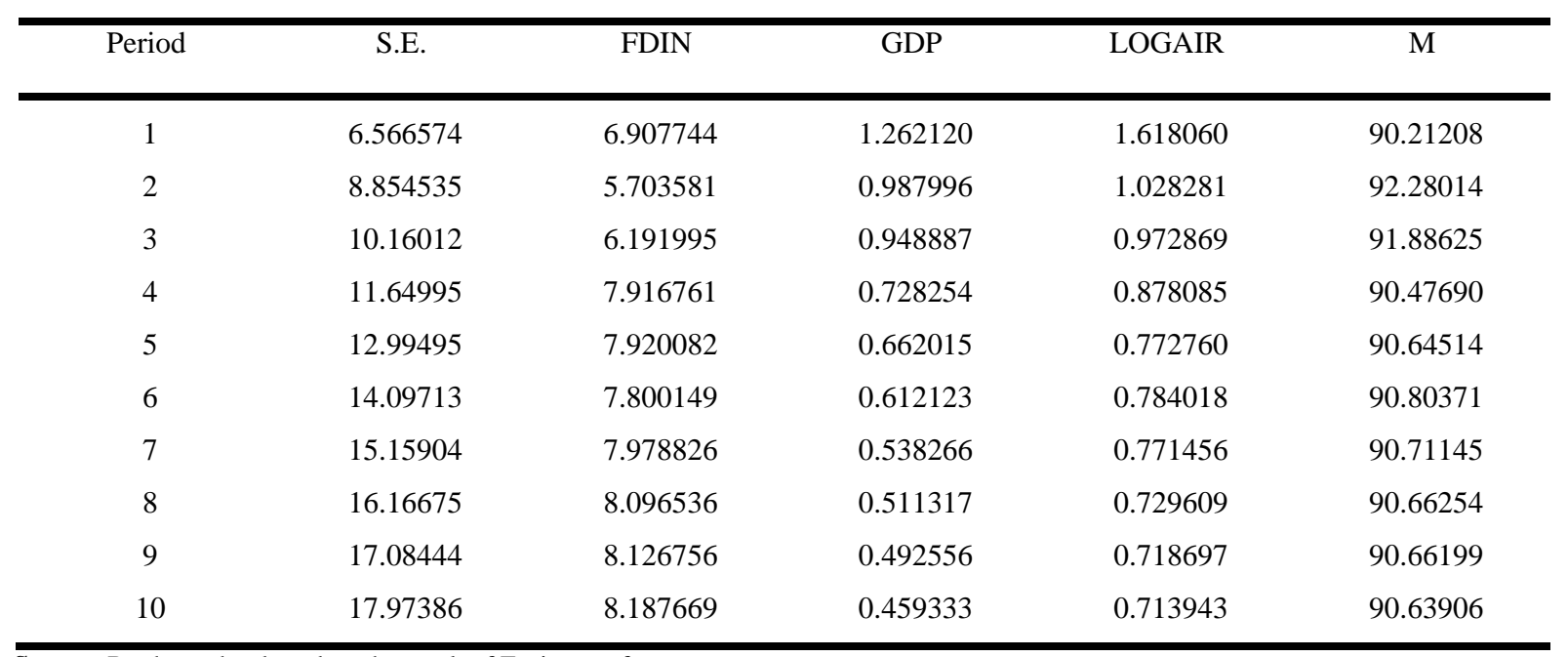

Source: By the author based on the result of E-views software.

\section{Conclusions and Policy Implication}

FDI inflows have a significant linkage with GDP in comparison to $\mathrm{Co} 2$ and $\mathrm{M}$. The increase of level of carbon dioxide emissions is highly related to FDI, where it is a major factor of air pollution. Accordingly, we conclude that GCC countries have not taken into account the environmental consideration. Furthermore, FDI inflows and commodity imports are correlated more than other variables studied, such as $\mathrm{Co} 2$ and GDP. For policy implication, GCC countries must assert its joint economic policy concerning accomplishing a sustained growth. A strict environmental policy is needed for reducing level of carbon dioxide emissions. This target could be measured via comparing the variance between FDI inflows and emissions. GCC economies must set a number of regulations related to this matter. This target could be achieved via attracting companies that use new technology and support environment friendliness in order to reduce share of FDI and imports in carbon dioxide emissions.

\section{References}

- Abdulai, A. R., Linda (2009). "The impact of trade and economic growth on the environment: revisiting the cross-country evidence." working paper, 1491. from http://www.ifw-kiel.de.

- Bruyn, S. M., Bergh J.C Van den., \& Opschoor, JB (1998). "Economic Growth and Emissions: reconsidering the empirical bases of Environmental Kuznets Curves "Ecological Economics (25): 161.

- Ekins, P. (1999). "Economic Growth and environmental sustainability- The Prospects for Green Growth, London.

- Fatimah Kari, A. S. (2012). "Growth, FDI, Imports and their Impact on Carbon Dioxide Emissions in GCC Countries: An Empirical Study.” Mediterranean Journal of Social Sciences 3(5): 25-31. 
- Fatimah Kari, A. S. (2013). "How much growth, FDI, and Imports affect the environment in GCC countries? An empirical analysis to air pollution issue." International Journal of Applied business Economic research 11(1).

- Greene, W. H. (2003). Econometric Analysis, 5/e, Pearson Education India.

- Kheder, S. B. (2010). "French FDI and pollution emissions: an empirical investigation, University of Paris.

- $\quad$ Lee, H.-H., Chang, Rae Kwon \& Koo, Chung Mo, (2005). "On the relationship between economic growth and environmental sustainability, 5th Ministerial conference on environment and development in Asia and pacific, 26, March, Seoul, Korea.

- Mukhopadhyay, K. (2008). "Environmental impact of Thailand's trade with OECD "The Asian scholar ejournal (issue No.3. ).

- Nickerson, B. A. (2004). "Modeling carbon dioxide emissions: Applying empirical and economic analysis to a global environmental issue, Ohio state university.

- Qader, M. R. (2009). "Electricity consumption and GHG emissions in GCC countries, energies 2, 12011213;dio:10.3390/en20401201. From: http://www.mdpi.com/journal/energies.

- Quentin, K. M., R (2002). "Growth and the environmental impact in Canada: An empirical Analysis, University of Ottawa.

- Saddam, A. (2014). Trade and Foreign Direct Investment: Impact on Economic Growth and Emissions in Gulf Cooperation Council Countries. Economics University of Malaya Ph.D: 374.

- Saddam, A. and F. Kari (2012). "Size of Economy, Cost of Transport and their impact on Trade in GCC countries: Evidence from qualitative and quantitative approaches." Journal of Finance and Investment Analysis 1(3): 137-169.

- Stern, D. I., Michael S. \& Barbier, Edward B (1996). "Economic Growth and environmental degradation: the Environmental Kuznets Curve and Sustainable Development." world development, 24 (7): 1151-1160.

- Thomas, S. M. (2009). Impact of economic growth on Co2 emissions: Trinidad case study. . 45th ISOCARP Congress 2009 Portugal. 